\title{
Visitor Satisfaction Analysis of Library Services at Sultan Agung Islamic University Using Libqual and Fuzzy
}

\author{
Andi Riansyah ${ }^{1}$, Nirmala Putri Pratama ${ }^{2}$, Badieah Assegaf ${ }^{3}$, \\ ${ }^{1}$ Universitas Islam Sultan Agung/Jurusan Teknik Informatika \\ JI.Raya Kaligawe KM.4, telp: 024-6583584, e-mail: andi@unissula.ac.id \\ ${ }^{2}$ Universitas Islam Sultan Agung/Jurusan Teknik Informatika \\ Jl.Raya Kaligawe KM.4, telp: 024-6583584, e-mail: badieah.assegaf@unissula.ac.id \\ ${ }^{3}$ Universitas Islam Sultan Agung/Jurusan Teknik Informatika \\ Jl.Raya Kaligawe KM.4, telp: 024-6583584, e-mail: nirmalaputripratama@unissula.ac.id
}

\section{ARTICLE INFO}

Article history:

Received 31 Maret 2020

Received in revised form 02 May 2020

Accepted 09 June 2020

Available online 31 July 2020
Quality of service is part of the services provided by the Universitas Islam Sultan Agung (UNISSULA) library so that it matches the expectations and needs of visitors. There is not yet a system that can be used to measure service quality so that the process of measuring services is less than optimal. So it needs to be made a system that can be used to evaluate the quality of library services. The system was built using two methods in its development, namely the Libqual Method and the Fuzzy Tsukamoto Method by using a Likert scale from values 1 to 5 . The Libqual method is used to measure the gap between perception and expectations with two calculations namely Adequancy Gap (AG) and Superiority Gap (SG), in Fuzzy Tsukamoto there are four process processes, namely fuzzyfication, rule formation, inference and defuzzyfication machines which are used as ranking of each question on the questionnaire regarding service quality. Ranking aims to find out the question items about the quality of service that has the best value on a scale from small to large. The results of calculations using Libqual and Fuzzy Tsukamoto from three dimensions that exist in Libqual, Library as Place gets first rank with a value of 3,31 which is the most optimal service quality.

Keywords: The quality service; Libqual; Fuzzy Tsukamoto

\section{ABSTRACT}

\section{Introduction}

Perpustakaan yang terdapat pada universitas sering digunakan oleh mahasiswa dalam mencari referensi untuk mengerjakan tugas maupun yang lainnya karena, perpustakaan dianggap sebagai sumber informasi yang paling lengkap oleh mahasiswa. Adanya perpustakaan diharap dapat membantu perguruan tinggi dalam mencapai tujuannya, dengan disediakannya fasilitas berupa buku dan koleksi yang disesuaikan kurikulum perguruan tinggi, program penelitian yang diterapkan, dan bentuk pengabdian yang telah menjadi dasar perguruan tinggi sebagai organisasi induk. Namun demikian, terdapat beberapa kendala dan kekurangan yang terdapat pada perpustakaan yang dirasa masih kurang oleh pengunjung perpustakaan. Objek penelitian terdapat pada perpustakaan pusat Universitas Islam Sultan Agung Semarang (UNISSULA).

Received May 31, 2020; Revised May 02, 2020; Accepted June 09, 2020 
Pelayanan merupakan harapan dari pengunjung dan apa yang nantinya akan diterima oleh pengunjung. Jika pelayanan yang diberikan jauh lebih baik melampui harapan maka pelayanan tersebut termasuk ke dalam pelayanan sesuai, namun bila pelayanan yang diberikan lebih rendah dari harapan maka pelayanan tersebut termasuk ke dalam pelayanan buruk. Untuk dapat mengetahui pelayanan yang diberikan sudah sesuai atau buruk diperlukan sebuah sistem yang dapat digunakan untuk mengetahui pelayanan dari perpustakaan. Sedangkan, perpustakaan pusat sendiri belum mempunyai sebuah sistem yang dapat digunakan oleh pengunjung dalam memberikan penilaiannya terhadap pelayanan yang diberikan oleh pihak perpustakaan sehingga dapat digunakan sebagai bahan untuk mengukur kualitas pelayanan perpustakaan dan dapat meningkatkan mutu dari pelayanan yang diberikan agar memberikan rasa yang lebih nyaman lagi kepada para pengunjung yang datang ke perpustakaan. Kualitas pelayanan dapat diartikan sebagai tuntutan kebutuhan dan keinginan pengunjung dari barang yang ditawarkan oleh suatu perusahaan atau organisasi dan ketepatan dalam penyampaian demi kebutuhan konsumen [1]. Dari permasalahan tersebut maka peneliti menggunakan 2 metode yang diguanakan untuk menyelesaikan permasalahan yang ada yaitu Metode Libqual dan Metode Fuzzy Tsukamoto. Pada metode Libqual (library quality) sendiri digunakan untuk mengetahui perbandingan antara persepsi dan harapan dari pengunjung perpustakaan terhadap pelayanan yang diberikan [2]. Sedangkan, Fuzzy Tsukamoto digunakan untuk perankingan dari output atau hasil pencarian dengan mengubah input (berupa himpunan fuzzy dari komposisi aturan fuzzy) menjadi suatu bilangan pada domain himpunan fuzzy tersebut. Terdapat 4 langkah didalam logika Fuzzy Tsukamoto yaitu fuzzyfikasi, pembentukan rule, mesin inferensi dan defuzzyfikasi. Dari penggunaan 2 metode tersebut akan menghasilkan tingkat kepuasan serta perangkingan dari kualitas pelayanan yang diberikan oleh perpustakaan menurut penilaian yang diberikan oleh pengunjung dan perpustakaan dapat menggunakan sebagai bahan evaluasi terhadap pelayanan yang telah diberikan.

\section{Research Method}

\subsection{Tinjauan Pustaka}

Dari penelitian sebelumnya tentang pengukuran tingkat kualitas pelayanan hanya menggunakan Metode Libqual. Maka berikut ini merupakan beberapa contoh kasus dalam pengukuran tingkat kualitas pelayanan dari suatu perusahaan :

a. Dari rujukan pertama [3] adalah mengenai analisis kualitas pelayanan perpustakaan pada perusahaan Soeman HS Provinsi Riau Pekanbaru dimana penelitian yang dilakukan untuk mengetahui harapan dan persepsi pemustaka terhadap kualitas pelayanan perpustakaan daerah. Penelitian ini menggunakan konsep kualitas pelayanan perpustakaan (affect of service, information control dan library as place) yang merupakan dimensi dari Libqual, menggunakan metode purposive sampling dalam pengambilan sampel untuk menentukan karakteristik tertentu, dan menggunakan metode Importance Performance Analysis (IPA). Terdapat kesenjangan $(G A P)$ yang terjadi antara harapan pemustaka dengan persepsi terhadap kinerja pelayanan perpustakaan daerah. Hal ini menunjukkan bahwa kinerja dari dimensi Libqual yang diberikan oleh perpustakaan daerah belum memenuhi harapan pemustaka.

b. Dari rujukan keempat dari penelitian [4] adalah mengenai pengukuran kualitas layanan digital library terhadap kepuasan pengunjung menggunakan metode Libqual yaitu pada penelitian ini menggunakan skala likert dengan tingkat jawaban yang digunakan terdiri dari 5 tingkatan, dimana skala likert digunakan untuk mengukur tanggapan atau respon seseorang tentang objek sosial. Dari hasil perhitungan menggunakan perhitungan AG dan SG pada libqual dapat diketahui bahwa kualitas layanan digital library pada perpustakaan sudah memiliki kualitas yang baik.

\subsection{Tahapan Pengumpulan Data}

Tahapan pengumpulan data yang dilakukan untuk membantu menyelesaikan penelitian. Berikut merupakan tahapan-tahapan yang digunakan. 
a. Wawancara

Proses wawancara dilakukan oleh peneliti kepada pihak pimpinan atau bagian pelayanan dari perpustakaan pusat yang bertujuan untuk medapatkan informasi yang dapat membantu dalam penelitian.

b. Kuisioner Online

Kuisioner online digunakan untuk mendapatkan data yang dapat digunakan pada proses perhitungan saat melakukan penelitian. Berikut merupakan kuesioner yang digunakan dalam penelitian :

Tabel 1 Item pertanyaan Kuesioner

\begin{tabular}{|c|c|c|}
\hline Dimensi & No & Pertanyaan \\
\hline & P1 & Petugas mengarahkan saat terjadi kesulitan dalam menelusur informasi \\
\hline $\begin{array}{l}\text { AjJect of } \\
\text { Service }\end{array}$ & P2 & $\begin{array}{l}\text { Petugas responsif dalam memberikan bantuan mencari informasi yang } \\
\text { saya perlukan }\end{array}$ \\
\hline Library & P3 & $\begin{array}{l}\text { Ketersediaan buku di perpustakaan dalam membantu saya } \\
\text { menyelesaikan berbagai tugas kuliah }\end{array}$ \\
\hline as Place & P4 & Ketenangan ruang perpustakaan untuk belajar \\
\hline & P5 & $\begin{array}{l}\text { Penataan koleksi perpustakaan memudahkan dalam proses temu } \\
\text { kembali informasi }\end{array}$ \\
\hline Control & P6 & $\begin{array}{l}\text { Kenyamanan waktu yang diberikan saat mencari informasi di } \\
\text { perpustakaan }\end{array}$ \\
\hline
\end{tabular}

\subsection{Skala Penilaian}

Skala penilaian pada penelitian ini menggunakan skala likert. Dikarenakan skala likert dapat memberikan nilai terhadap sesuatu kualitas ataupun yang lainnya. Penggunaan data dalam penelitian ini berupa data kuantitatif sehingga menggunakan bentuk skala likert merupakan skala psikometrik yang umum digunakan didalam kuesioner dan skala yang paling banyak digunakan didalam riset berupa survei [5] seperti pada tabel 3 .

Tabel 2 Skala penilaian

\begin{tabular}{ccc}
\hline No & Skala & Nilai \\
\hline 1. & Sangat Tidak Puas (STP) & 1 \\
2. & Tidak Puas (TP) & 2 \\
3. & Cukup Puas (CP) & 3 \\
4. & Puas (P) & 4 \\
5. & Sangat Puas (SP) & 5 \\
\hline
\end{tabular}

\subsection{Alur Proses Data}

Alur proses data yang digunakan untuk penelitian terlihat pada gambar 1 . 


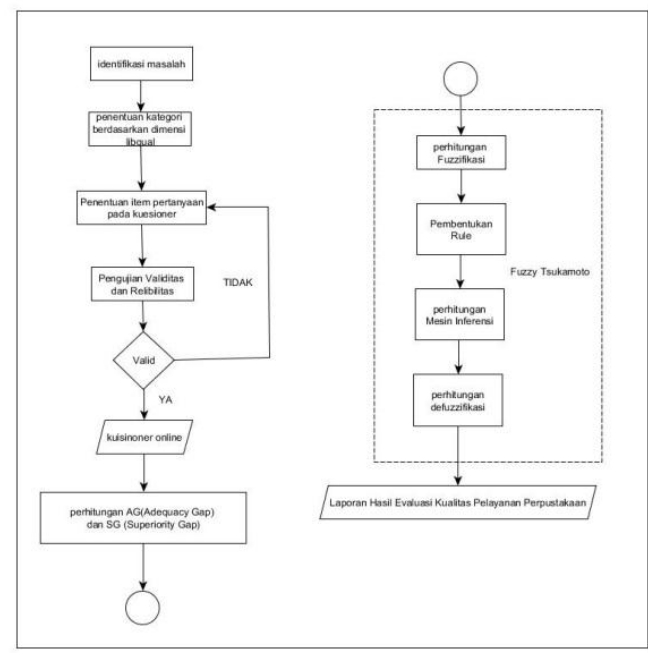

Gambar 1 Alur Proses Data

Pada gambar 1 alur proses data merupakan identifikasi masalah yang terjadi pada perpustaakaan sehingga dapat menentukan kategori pada setiap dimensi yang digunakan dalam metode Libqual. Pada proses selanjutnya menentukan item pertanyaan yang dimasukkan ke dalam kuesioner, setelah item pertanyaan ditentukan maka akan diuji validitas dan reliabilitasnya apakah hasil dari pengujian tersebut menunjukkan bahwa item pertanyaan yang diuji valid atau tidak. Jika tidak valid maka harus menentukan item pertanyaan kembali, jika hasilnya valid maka akan masuk ke proses pengisian kuesioner secara online oleh pengunjung perpustakaan. Setelah mendapatkan data dari pengunjung maka dilakukan perhitungan AG (Adequancy Gap) dan SG (Superiority Gap) berguna untuk mengetahui kesenjangan anatara persepsi, harapan minimum dan harapan ideal dari pertanyaan yang diberikan. Setelah selesai melakukan perhitungan maka dilanjutkan dengan perhitungan fuzzy Tsukamoto dengan proses awal melakukan perhitungan fuzzifikasi, setelah didapatkan hasill dari fuzzifikasi maka masuk ke pembentukan rule yang akan digunakan pada perhitungan mesin ineferensi dan proses yang terakhir yaitu perhitungan defuzzifikasi untuk menghasilkan nilai crisp. Setelah semua proses perhitungan selesai maka hasil dari semua perhitungan akan masuk ke dalam laporan evaluasi Kepuasan Pengunjung.

\subsection{Metode Libqual}

Metode Libqual digunakan untuk mengukur kepuasan pengunjung perpustakaan dengan cara menghitung nilai AG (Adequancy Gap) dan SG (Superiority Gap) yang berfungsi untuk mendapatkan tingkat kesenjangan antara persepsi, harapan minimum dan harapan ideal. Sehingga perpustakaan dapat mengetahui pelayanan yang telah diberikan telah sesuai dengan harapan dari pengunjung perpustakaan atau belum. Dari hasil tersebut dapat dilihat bahwa pelayanan mana saja yang nantinya akan diperbaiki dan yang harus dipertahankan. Berikut ini merupakan rumus dari AG dan SG [6] :

a. Rumus AG (Adequancy Gap)

$$
\mathrm{AG}=\mathrm{P}(\text { persepsi) }-\mathrm{HM}(\text { Harapan Minimum })
$$

b. Rumus SG (Superiority Gap)

$$
\mathrm{SG}=\mathrm{P}(\text { Persepsi })-\mathrm{HI}(\text { Harapan Ideal })
$$

\subsection{Importance Performance Analysis (IPA)}


Importance-Performance Analysis (IPA) adalah metode statistik dengan corak deskriptif dimana teknik ini sangat berguna untuk mengevaluasi elemen elemen pemasaran dan diperkenalkan pertama kali oleh John A Martilla dan John C. James tahun 1977. Fitur yang menarik dari metode ini adalah hasil / output yang dihasilkan dapat diperlihatkan dalam bentuk grafik pada bentuk dua dimensi, yang mudah untuk diinterpretasikan. Analisa ini juga mengaitkan antara tingkat kepentingan (importance) suatu atribut yang dimiliki obyek tertentu dengan kenyataan (performance) yang dirasakan oleh pengguna.

Indeks Kepuasan Pengguna (IKP) adalah analisa kuantitatif berupa persentase pengguna yang senang terhadap suatu survei kepuasan pengguna. IKP berfungsi mengetahui tingkat kepuasan user secara menyeluruh dengan memperhatikan tingkat kepentingan dari atribut produk atau jasa. Karena nilai Skor tertinggi pada skala pengukuran yang dipakai pada penelitian adalah 5 maka rumus IKP menjadi [7]:

$\mathrm{IKP}=\frac{\mathrm{T}}{5 \mathrm{Y}} \times 100 \%$

Keterangan:

$\mathrm{T}=$ Rata -rata kepentingan (I) dikali dengan jumlah rata-rata kinerja $(\mathrm{P})$.

$5=$ Skor tertinggi pada skala pengukuran.

$\mathrm{Y}=$ Jumlah dari rata-rata kepentingan (I)

IKP kurang dari 50\% maka kepuasan pengunjung Tidak Puas.

IKP lebih dari 50\% sampai dengan kurang dari $80 \%$ maka kepuasan pengunjung Cukup Puas.

IKP lebih dari 80\% maka kepuasan pengunjung Sangat Puas.

\subsection{Metode Fuzzy Tsukamoto}

Representasi dari Fuzzy Tsukamoto menggunakan himpunan dengan fungsi keanggotan yang monoton, yang digunakan sebagai nilai output atau hasil yang dicari dengan mengubah nilai input menjadi bilangan pada domain himpunan fuzzy. Terdapat 4 konfigurasi sistem di dalam logika Fuzzy Tsukamoto yaitu [8][9][10]:

a. Fuzzifikasi

Pada penelitian ini menggunakan derajat keanggotaan segitiga, dengan rumus berikut :

$$
\mu[x, a, b, c]=\left\{\begin{array}{lr}
0 & ; x \leq a \text { atau } x \geq c \\
(x-a) /(b-a) ; a \leq x \leq b \\
(c-x) /(c-b) ; b \leq x \leq c
\end{array}\right.
$$

b. Pembentukan Rule

Menentukan komposisi pada aturan yang berbentuk IF-THEN yang harus direpresentasikan dengan himpunan fuzzy dan fungsi keanggotaan yang monoton.

$$
\text { if ( } x \text { is } A \text { ) and ( } y \text { is } B \text { ) then ( } z \text { is } C \text { ) }
$$

c. Mesin Inferensi

Menentukan pengaplikasi fungsi implikasi yang digunakan pada mesin inferensi adalah MIN. sistem pada mesin inferensi yaitu kerangka yang didasari oleh teori himpunan fuzzy, aturan fuzzy dan penalaran fuzzy secara garis besar yang berbentuk diagram blok proses inferensi.

d. Defuzzifikasi 
Pada proses defuzzifikasi dari himpunan fuzzy yang telah diperoleh dari aturan fuzzy dan output yang berasal dari hasil bilangan pada domain fuzzy itu sendiri. Untuk memperoleh nilai crisp atau nilai tegas, dengan cara mengubah input menjadi domain himpunan fuzzy. Berikut merupakan rumus dari defuzzifikasi :

$$
\mathrm{Z}=\frac{\sum \mu_{\mathrm{i}} \mathrm{z}_{\mathrm{i}}}{\sum \mu_{\mathrm{i}}}
$$

\section{Results and Analysis}

Pada penelitian ini menggunakan sampel dari pengunjung perpustakaan sebanyak 99 orang. Yang diambil dari data pengunjung perpustakaan selama tahun 2018 dimulai pada bulan januari hingga bulan desember dengan total keseluruhan dari pengunjung perpustakaan sebanyak 77.914 orang. Total keseluruhan pengunjung selama tahun 2018 tersebut kemudian di rata-rata menjadi 8093 orang. Cara untuk mendapatkan sampel yang digunakan pada penelitian diambil dengan cara menghitung nilai rata-rata populasi dengan menggunakan metode solvin [11]. :

\subsection{Hasil Perhitungan Libqual}

Libqual digunakan untuk mengukur kesenjangan yang terdapat pada presepsi, harapan minimum dan harapan ideal. Libqual bertujuan agar dapat mengukur tingkat kepuasan pengunjung terhadap pelayanan yang diberikan oleh perpustakaan. Berikut merupakan hasil dari perhitungan Libqual :

Tabel 3 Perhitungan nilai AG dan SG setiap pertanyaan

\begin{tabular}{ccccc} 
No & Pertanyaan & Persepsi & $\begin{array}{c}\text { Harapan } \\
\text { Minimum }\end{array}$ & $\begin{array}{c}\text { Harapan } \\
\text { Ideal }\end{array}$ \\
\hline 1 & $\begin{array}{c}\text { Affect of } \\
\text { Service P1 } \\
\text { Affect of }\end{array}$ & 3,51 & 3,26 & 4,05 \\
2 & $\begin{array}{c}\text { Service P2 } \\
\text { Library as }\end{array}$ & 3,61 & 3,24 & 4,11 \\
4 & $\begin{array}{c}\text { Place P3 } \\
\text { Library as } \\
\text { Place P4 }\end{array}$ & 3,43 & 3,55 & 4,28 \\
5 & $\begin{array}{c}\text { Personal } \\
\text { Control P5 }\end{array}$ & 3,59 & 3,44 & 4,21 \\
6 & $\begin{array}{c}\text { Personal } \\
\text { Control P6 }\end{array}$ & 3,60 & 3,53 & 4,15 \\
& Jumlah & 21,54 & & 24,94 \\
\hline
\end{tabular}

Pada tabel 4 merupakan gabungan dari tabel 3 yang berupa hasil dari perhitungan nilai AG dan SG pada setiap pertanyaan.

Tabel 4 Perhitungan nilai AG dan SG setiap pertanyaan (2)

No AG SG IKP $\begin{gathered}\text { Tingkat } \\ \text { Kepuasan }\end{gathered}$

\begin{tabular}{lllll}
1 & 0,25 & $-0,55$ & $69,96 \%$ & Cukup Puas \\
\hline
\end{tabular}




\begin{tabular}{ccccc}
2 & 0,36 & $-0,51$ & $71,00 \%$ & Cukup Puas \\
3 & 0,25 & $-0,48$ & $73,93 \%$ & Cukup Puas \\
4 & 0,02 & $-0,71$ & $71,51 \%$ & Cukup Puas \\
5 & 0,14 & $-0,63$ & $72,72 \%$ & Cukup Puas \\
6 & 0,07 & $-0,56$ & $71,68 \%$ & Cukup Puas \\
& Jumlah & $-3,44$ & $429,80 \%$ & \\
\hline
\end{tabular}

Tabel 5 Perhitungan nilai AG dan SG setiap dimensi

\begin{tabular}{ccccc} 
No & $\begin{array}{c}\text { Dimensi } \\
\text { Pelayanan }\end{array}$ & Persepsi & $\begin{array}{c}\text { Harapan } \\
\text { Minimum }\end{array}$ & $\begin{array}{c}\text { Harapan } \\
\text { Ideal }\end{array}$ \\
\hline 1 & $\begin{array}{c}\text { Affect of } \\
\text { Service }\end{array}$ & 3,56 & 3,25 & 4,08 \\
2 & $\begin{array}{c}\text { Library } \\
\text { as Place }\end{array}$ & 3.61 & 3,48 & 4,21 \\
3 & $\begin{array}{c}\text { Personal } \\
\text { Control }\end{array}$ & 3,60 & 3,49 & 4,18 \\
& Jumlah & 10,77 & & 12,47 \\
\hline
\end{tabular}

Pada tabel 6 merupakan gabungan dari tabel 5 yang berupa hasil dari perhitungan nilai AG dan SG pada setiap pertanyaan.

\begin{tabular}{ccccc}
\multicolumn{6}{c}{ Tabel 6 Perhitungan nilai AG dan SG setiap dimensi } \\
\hline No & AG & SG & IKP & $\begin{array}{c}\text { Tingkat } \\
\text { Kepuasan }\end{array}$ \\
\hline 1 & 0,31 & $-0,52$ & $70,47 \%$ & Cukup Puas \\
2 & 0,13 & $-0,60$ & $72,72 \%$ & Cukup Puas \\
3 & 0,11 & $-0,58$ & $72,21 \%$ & Cukup Puas \\
& Jumlah & $-1,70$ & $215,40 \%$ & \\
\hline
\end{tabular}

Dari hasil perhitungan Libqual menggunakan IKP maka dapat disimpulkan bahwa dimensi pelayanan pada perpustakaan yang terdiri dari Affect of Service, Library as Place, Personal Control sudah mencapai tingkat kepuasan "Cukup Puas" karena hasil IKPnya sudah lebih dari $50 \%$.

\subsection{Hasil Perhitungan Fuzzy Tsukamoto}

Perhitungan Fuzzy Tsukamoto diperuntukan untuk menghasilkan nilai tegas (crisp) yang dapat digunakan untuk klasifikasi kepuasan pengunjung terhadap pelayanan perpustakaan. Terdapat 3 variabel yang digunakan pada perhitungan variabel yaitu persepsi rata-rata 3,51, harapan minimum rata-rata 3,26 dan harapan ideal memiliki rata-rata 4,05. Berikut merupakan contoh perhitungan Fuzzy Tsukamoto:

1. Fuzzifikasi

Fuzzifikasi dipergunakan untuk mengubah data variabel numerik ke dalam bentuk derajat keanggotaan yang nantinya digunakan sebagai perhitungan fuzzy. Berikut merupakan hasil dari perhitungan fuzzifikasi. 
Tabel 7 Fuzzifikasi

\begin{tabular}{ccc} 
Pertanyaan & Alat Pengukur & $\begin{array}{c}\text { Nilai } \\
\text { rata-rata }\end{array}$ \\
\hline \multirow{2}{*}{ P1 } & Persepsi & 3,51 \\
& Harapan Minimum & 3,26 \\
& Harapan Ideal & 4,05 \\
P2 & Persepsi & 3,61 \\
& Harapan Minimum & 3,24 \\
P3 & Harapan Ideal & 4,11 \\
& Persepsi & 3,80 \\
P4 & Harapan Minimum & 3,55 \\
& Harapan Ideal & 4,28 \\
& Persepsi & 3,43 \\
& Harapan Minimum & 3,41 \\
P5 & Harapan Ideal & 4,14 \\
& Persepsi & 3,59 \\
& Harapan Minimum & 3,44 \\
& Harapan Ideal & 4,21 \\
& Harapan Minimum & 3,60 \\
& Harapan Ideal & 4,15 \\
\hline
\end{tabular}

Pada tabel 8 dan 9 merupakan gabungan dari tabel 7 dimana isi dari tabel 8 dan 9 adalah hasil dari perhitungan fuzzifikasi.

Tabel 8 Fuzzifikasi (2)

\begin{tabular}{cccccc}
\hline \multirow{2}{*}{ No } & \multicolumn{5}{c}{ Derajat Keanggotaan } \\
\cline { 2 - 6 } & STP & TP & CP & P & SP \\
\hline \multirow{3}{*}{1} & 0 & 0 & 0,49 & 0,51 & 0 \\
& 0 & 0 & 0,74 & 0,26 & 0 \\
& 0 & 0 & 0 & 0,95 & 0,05 \\
\hline \multicolumn{6}{c}{ Tabel 9 Fuzzifikasi (Lanjutan) } \\
\hline \multirow{6}{*}{ No } & \multicolumn{6}{c}{ Derajat Keanggotaan } \\
\cline { 2 - 6 } & STP & TP & CP & P & SP \\
\hline \multirow{4}{*}{2} & 0 & 0 & 0,39 & 0,61 & 0 \\
& 0 & 0 & 0,76 & 0,24 & 0 \\
& 0 & 0 & 0 & 0,89 & 0,11 \\
3 & 0 & 0 & 0,20 & 0,80 & 0 \\
& 0 & 0 & 0,45 & 0,55 & 0 \\
& 0 & 0 & 0 & 0,72 & 0,28 \\
4 & 0 & 0 & 0,57 & 0,43 & 0 \\
& 0 & 0 & 0,59 & 0,41 & 0 \\
5 & 0 & 0 & 0 & 0,86 & 0,14 \\
5 & 0 & 0 & 0,41 & 0,59 & 0 \\
\hline
\end{tabular}




\begin{tabular}{cccccc}
\hline & 0 & 0 & 0,56 & 0,44 & 0 \\
& 0 & 0 & 0 & 0,79 & 0,21 \\
& 0 & 0 & 0,40 & 0,60 & 0 \\
6 & 0 & 0 & 0,47 & 0,53 & 0 \\
& 0 & 0 & 0 & 0,85 & 0,15 \\
\hline
\end{tabular}

2. Pembentukan Rule

Tabel 10 Pembentukan Rule

\begin{tabular}{|c|c|}
\hline Rule & Keterangan \\
\hline R1 & $\begin{array}{l}\text { IF P STP AND HM STP AND HI STP THE } \\
\text { kepuasan STP }\end{array}$ \\
\hline R2 & $\begin{array}{l}\text { IF P TP AND HM TP AND HI TP THEN } \\
\text { kepuasan TP }\end{array}$ \\
\hline R3 & $\begin{array}{l}\text { IF P CP AND HM CP AND HI CP THEN } \\
\text { kepuasan CP }\end{array}$ \\
\hline R4 & IF P P AND HM P AND HI P THEN kepuasan P \\
\hline R5 & $\begin{array}{l}\text { IF P SP AND HM SP AND HI SP THEN } \\
\text { kepuasan SP }\end{array}$ \\
\hline R25 & $\begin{array}{l}\text { IF P TP AND HM P AND HI P THEN kepuasan } \\
\text { TP }\end{array}$ \\
\hline
\end{tabular}

3. Mesin Inferensi

Tabel 11 Mesin Inferensi

\begin{tabular}{ccc}
\hline \multirow{2}{*}{ Rule } & \multicolumn{2}{c}{ Mesin Inferensi } \\
\cline { 2 - 3 } & $\mathrm{A}$ & $\mathrm{z}$ \\
\hline R1 & 0 & 2 \\
R2 & 0 & 1 \\
R3 & 0 & 2 \\
R4 & 0,26 & 3,26 \\
R5 & 0 & 5 \\
$\ldots$ & $\ldots$ & $\ldots$ \\
R25 & 0 & 1 \\
\hline
\end{tabular}

4. Defuzzifikasi

Dari perhitungan defuzzyfikasi nilai derajat keanggotaan persepsi, harapan minimum dan harapan ideal mendapatkan hasil nilai crisp. Berikut ini merupakan tabel hasil dari keseluruhan perhitungan defuzzifikasi yang menghasilkan nilai crisp :

Tabel 12 Perhitungan fuzzy tsukamoto setiap pertanyaan

\begin{tabular}{cccccc} 
No & $\begin{array}{c}\text { Variabel } \\
\text { /Pertanyaan }\end{array}$ & Persepsi & $\begin{array}{c}\text { Harapan } \\
\text { Minimum }\end{array}$ & $\begin{array}{c}\text { Harapan } \\
\text { Ideal }\end{array}$ & $\begin{array}{c}\text { Nilai } \\
\text { Crisp }\end{array}$ \\
\hline 1 & $\begin{array}{c}\text { Affect of } \\
\text { Service } \mathrm{P} 1\end{array}$ & 3,51 & 3,26 & 4,05 & 2,93 \\
2 & Affect of & 3,61 & 3,24 & 4,11 & 3,01 \\
\hline
\end{tabular}

Visitor Satisfaction Analysis of Library Services at Sultan Agung Islamic University Using Libqual and Fuzzy (Andi Riansyah) 


\begin{tabular}{|c|c|c|c|c|c|}
\hline \multicolumn{6}{|c|}{ Service P2 } \\
\hline 3 & $\begin{array}{c}\text { Library as } \\
\text { Place P3 }\end{array}$ & 3,80 & 3,55 & 4,28 & 3,16 \\
\hline 4 & $\begin{array}{c}\text { Library as } \\
\text { Place P4 }\end{array}$ & 3,43 & 3,41 & 4,14 & 2,94 \\
\hline 5 & $\begin{array}{c}\text { Personal } \\
\text { Control P5 }\end{array}$ & 3,59 & 3,44 & 4,21 & 3,03 \\
\hline 6 & $\begin{array}{c}\text { Personal } \\
\text { Control P6 } \\
\end{array}$ & 3,60 & 3,53 & 4,15 & 3,02 \\
\hline \multicolumn{6}{|c|}{ Tabel 13 Perhitungan fuzzy tsukamoto setiap dimensi } \\
\hline No & Dimensi & Persepsi & $\begin{array}{c}\text { Harapan } \\
\text { Minimum }\end{array}$ & $\begin{array}{c}\text { Harapan } \\
\text { Ideal }\end{array}$ & $\begin{array}{l}\text { Nilai } \\
\text { Crisp }\end{array}$ \\
\hline 1 & $\begin{array}{l}\text { Affect of } \\
\text { Service }\end{array}$ & 3,56 & 3,25 & 4,08 & 3,07 \\
\hline 2 & $\begin{array}{c}\text { Library } \\
\text { as Place }\end{array}$ & 3.61 & 3,48 & 4,21 & 3,31 \\
\hline 3 & $\begin{array}{c}\text { Personal } \\
\text { Control }\end{array}$ & 3,60 & 3,49 & 4,18 & 3,18 \\
\hline
\end{tabular}

\subsection{Kesimpulan Perhitungan}

Dari hasil perhitungan antara metode Libqual dan Fuzzy Tsukamoto maka dapat disimpulkan bahwa hasilnya sebagai berikut :

Tabel 14 Hasil perangkingan

\begin{tabular}{ccccc}
\hline No & $\begin{array}{c}\text { Variabel } \\
\text { /Pertanyaan }\end{array}$ & Persepsi & $\begin{array}{c}\text { Harapan } \\
\text { Minimum }\end{array}$ & $\begin{array}{l}\text { Harapan } \\
\text { Ideal }\end{array}$ \\
\hline 1 & $\begin{array}{c}\text { Library as } \\
\text { Place P3 }\end{array}$ & 3,80 & 3,55 & 4,28 \\
2 & $\begin{array}{c}\text { Personal } \\
\text { Control P5 } \\
3\end{array}$ & 3,59 & 3,44 & 4,21 \\
& $\begin{array}{c}\text { Personal } \\
\text { Control P6 } \\
\text { Affect of }\end{array}$ & 3,60 & 3,53 & 4,15 \\
4 & Service P2 & 3,61 & 3,24 & 4,11 \\
\hline
\end{tabular}

Tabel 15 Hasil perangkingan (Lanjutan)

\begin{tabular}{ccccc}
\hline No & $\begin{array}{c}\text { Variabel } \\
\text { /Pertanyaan }\end{array}$ & Persepsi & $\begin{array}{c}\text { Harapan } \\
\text { Minimum }\end{array}$ & $\begin{array}{c}\text { Harapan } \\
\text { Ideal }\end{array}$ \\
\hline 5 & $\begin{array}{c}\text { Library as } \\
\text { Place } \mathrm{P} 4\end{array}$ & 3,43 & 3,41 & 4,14 \\
6 & $\begin{array}{c}\text { Affect of } \\
\text { Service } \mathrm{P} 1\end{array}$ & 3,51 & 3,26 & 4,05 \\
\hline
\end{tabular}

Pada tabel 16 merupakan gabungan dari tabel 14 dan 15 dimana isi dari tabel 16 adalah hasil perangkingan dari setiap pertanyaan. 
Tabel 16 Hasil perangkingan (2)

\begin{tabular}{cccccc}
\hline No & AG & SG & $\begin{array}{c}\text { Nilai } \\
\text { Crisp }\end{array}$ & $\begin{array}{c}\text { Tingkat } \\
\text { Kepuasan }\end{array}$ & Rangking \\
\hline 1 & 0,25 & $-0,48$ & 3,16 & Cukup Puas & 1 \\
2 & 0,14 & $-0,63$ & 3,03 & Cukup Puas & 2 \\
3 & 0,07 & $-0,56$ & 3,02 & Cukup Puas & 3 \\
4 & 0,36 & $-0,51$ & 3,01 & Cukup Puas & 4 \\
5 & 0,02 & $-0,71$ & 2,94 & Cukup Puas & 5 \\
6 & 0,25 & $-0,55$ & 2,93 & Cukup Puas & 6 \\
\hline
\end{tabular}

Tabel 17 Hasil Perangkingan Dimensi

\begin{tabular}{ccccc}
\hline No & $\begin{array}{c}\text { Variabel } \\
\text { /Pertanyaan }\end{array}$ & Persepsi & $\begin{array}{c}\text { Harapan } \\
\text { Minimum }\end{array}$ & $\begin{array}{c}\text { Harapan } \\
\text { Ideal }\end{array}$ \\
\hline 1 & $\begin{array}{c}\text { Libraryas } \\
\text { Place }\end{array}$ & 3.61 & 3,48 & 4,21 \\
2 & $\begin{array}{c}\text { Personal } \\
\text { Control } \\
\text { Affect of } \\
\text { Service }\end{array}$ & 3,60 & 3,49 & 4,18 \\
\hline
\end{tabular}

Pada tabel 18 merupakan gabungan dari tabel 17 dimana isi dari tabel 18 adalah hasil perangkingan dari setiap dimensi.

Tabel 18 Hasil Perangkingan Dimensi (2)

\begin{tabular}{cccccc}
\hline No & AG & SG & $\begin{array}{c}\text { Nilai } \\
\text { Crisp }\end{array}$ & $\begin{array}{c}\text { Tingkat } \\
\text { Kepuasan }\end{array}$ & Rangking \\
\hline 1 & 0,13 & $-0,60$ & 3,31 & Cukup Puas & 1 \\
2 & 0,11 & $-0,58$ & 3,18 & Cukup Puas & 2 \\
3 & 0,31 & $-0,52$ & 3,07 & Cukup Puas & 3 \\
\hline
\end{tabular}

\section{Keterangan :}

Perhitungan Libqual menghasilkan nilai kesenjangan antara persepsi dan harapan minimum $(A G)$ terdapat pada nilai yang positif serta kesenjangan antara persepsi dan harapan ideal (SG) terdapat pada nilai negatif yang berarti bahwa pelayanan yang diberikan oleh perpustakaan masih terdapat dalam batas toleransi. Dimana pada tingkat kepuasan masing - masing pelayanan yang diberikan oleh perpustakaan pusat masih dalam kategori "Cukup Puas" sehingga harus dilakukan perbaikan pelayanan agar pengunjung perpustakaan dapat merasa puas dan nyaman dengan pelayanan yang diberikan. Metode Fuzzy Tsukamoto digunakan untuk memperjelas hasil yang didapatkan dari perhitungan metode Libqual yaitu dengan menambahan peringkat dari setiap item pertanyaan dan dimensi pelayanan. Pada hasil perhitungan metode Fuzzy Tsukamoto telah didapatkan urutan rangking dari setiap itempertanyaan pada pelayanan yang diberikan oleh perpustakaan dimana "Library as Place P3" mendapatkan peringkat 1 atau mendapatkan hasil penilaian tertinggi dari pengunjung dan untuk dimensi pelayanan rangking 1 didapatkan oleh 
"Library as Place" dengan skala penilaian dari kecil ke besar. Dari keseluruhan hasil yang diperoleh pelayanan perpustakaan yang memiliki peringkat terendah yang harus segera dilakukan perbaikan.

\section{Conclusion}

Berdasarkan hasil penelitian, dapat disimpulakan bahwa mengenai kepuasan pengunjung terhadap pelayanan yang berada pada perpustakaan pusat UNISSULA menggunakan metode Libqual dan Fuzzy Tsukamoto dapat diperuntukan untuk mengetahui kepuasan pengunjung terhadap pelayanan perpustakaan sehingga, pelayanan yang diberikan dapat sesuai dengan harapan pengunjung. Hasil perhitungan menggunakan metode Libqual dan Fuzzy Tsukamoto bertujuan untuk mengetahui item pertanyaan mengenai pelayanan yang diberikan oleh perpustakaan yang mendapatkan nilai terbaik dengan skala penilaian dari kecil ke besar. Hasil dari perhitungan menggunakan metode Libqual Fuzzy Tsukamoto dapat digunakan sebagai bahan evaluasi pelayanan perpustakaan dimana dari tiga dimensi yang ada pada Libqual, Library as Place mendapatkan peringkat pertama dengan nilai 3,31 yang merupakan kualitas pelayanan yang paling optimal.

\section{References}

[1] Dimas S. And Oktafani F., "Effect On The Quality Of Customer Satisfaction Futsal," No. September, 2014.

[2] Fatmawati E., Mata Baru Penelitian Perpustakaan Dari Servsqual Ke Libqual. 2017.

[3] S. Restuti, "Analisis Kualitas Pelayanan Perpustakaan ( Libqual+Tm Method )," Pekbis J., Pp. 202211, 2013.

[4] E. Nurvia And Angraini, "Pengukuran Kualitas Layanan Digital Library Libqual ( Studi Kasus: Perpustakaan Badan Pusat Statistik Provinsi Riau )," J. Rekayasa Dan Manaj. Inf., Vol. 2, No. 2, Pp. 30-38, 2016.

[5] Maryuliana, "Sistem Informasi Angket Pengukuran Skala Kebutuhan Materi Pembelajaran Tambahan Sebagai Pendukung Pengambilan Keputusan Di Sekolah Menengah Atas Menggunakan Skala Likert," Vol. 1, No. 2, Pp. 1-12, 2016.

[6] Rahayuningsih F., Mengukur Kualitas Pemustaka Menggunakan Metode Libqual+Tm. Yogyakarta: Graha Ilmu, 2015.

[7] Faidah A. N., "Analisis Kualitas Pelayanan Dengan Metode Libqual +Tm (Studi Pada Perpustakaan Fakultas Ekonomi Dan Bisnis Universitas Lambung Mangkurat Banjarmasin)," Pros. Semin. Nas. Asbis, Pp. 60-69, 2016.

[8] Irwansyah A., "Rancang Bangun Aplikasi Monitoring Tingkat Kualitas Layanan Perpustakaan Menggunakan Fuzzy Tsukamoto,” Sist. Dan Teknol. Inf., Vol. 5, No. 1, Pp. 27-29, 2017.

[9] Riansyah A. And Kurniadi D., "Fuzzy Tsukamoto Implementation On Internet Of Things To Control Flooding," Vol. 17, No. 2, Pp. 171-176, 2020.

[10] Haddin M., Marwanto A., Ismail M., Riansyah A., "Data Acquisition In Determining Lab Work Assesment Ranking Using Fuzzy Analytic Hierarchy Process (Fahp).” Ieee, Pp. 346-353, 2019.

[11] Ginting S., "Penerapan Metode Fuzzy Service Quality Untuk Melihat Kepuasan Nasabah Terhadap Pelayanan Pt. Bank," 2018. 